\title{
Secondary myelodysplastic syndrome/acute myeloid leukaemia following mitoxantrone-based therapy for breast carcinoma
}

\author{
R Saso', S Kulkarni², P Mitchell ${ }^{3}$, J Treleaven', GJ Swansbury ${ }^{4}$, J Mehta ${ }^{5}$, R Powles², S Ashley ${ }^{6}$, A Kuan ${ }^{7}$ \\ and T Powles ${ }^{2}$
}

Departments of ${ }^{1}$ Haematology, ${ }^{2}$ Medical Oncology, ${ }^{4}$ Cytogenetics and ${ }^{7}$ Statistics, The Royal Marsden Hospital, Downs Road, Sutton SM2 5PT, UK; ${ }^{3}$ Austin \& Repatriation Medical Centre, West Heidelberg, Victoria, Australia; ${ }^{5}$ Division of Transplantation Medicine, University of South Carolina, Columbia SC 29203 USA, ${ }^{6}$ Thames Cancer Registry, London, UK

Summary Of 1774 patients with breast cancer given mitoxantrone (MTZ) with methotrexate $(n=492)$ or with methotrexate and mitomycin $\mathrm{C}(n=1282)$, nine developed MDS/AML after a median of 2.5 years. Median duration of survival from diagnosis of MDS/AML was 10 months and six patients died. The crude incidence of developing MDS/AML after MMM or MM chemotherapy was 15 per 100000 patient years followup, while the actuarial risk was $1.1 \%$ and $1.6 \%$ at 5 and 10 years respectively. MTZ-based regimens carry a $10 \times$ higher risk of subsequent MDS/AML compared to that seen in the general population. (C) 2000 Cancer Research Campaign

Keywords: myelodysplastic syndrome; acute myeloid leukaemia; breast cancer; mitoxantrone

Significant improvement in the management of breast carcinoma has been achieved over the last few decades, mostly because of the use of combinations of surgery, radiotherapy and chemoendocrine therapy (Powles et al, 1995; Fisher et al, 1997). Adjuvant and neoadjuvant chemotherapy is delivered with the intention of controlling micrometastases. The 20-year follow-up of the first combination chemotherapy regimen reported by Bonadonna et al (1995) involved cyclophosphamide, methotrexate and 5-fluorouracil. Various other combinations have been tried, and use of anthracyclines is reported to improve the results (Brincker et al, 1983); mitoxantrone has been tried in place of doxorubicin and may have fewer side-effects (Powles et al, 1991).

A number of chemotherapy drugs, especially alkylating agents and some anthracyclines used in breast cancer treatment, are associated with increased risk of secondary acute myeloid leukaemia (sAML) or myelodysplasia (MDS), (Pedersen-Bjergaard and Rowley, 1994). This analysis was undertaken in breast cancer patients to ascertain whether there is a similar risk of secondary AML/MDS associated with mitoxantrone.

\section{PATIENTS AND METHODS}

The prospectively maintained database at the Royal Marsden Hospital was used to identify patients with breast carcinoma treated with mitoxantrone-based regimens in the period 1984-1995. Patients who developed leukaemia or MDS were identified in the Royal Marsden Hospital database and also by accessing data reported to the Thames Cancer Registry. Details from these sources were cross-checked and found to be consistent.

Received 23 November 1999

Revised 23 February 2000

Accepted 23 February 2000

Correspondence to: JG Treleaven

\section{Chemotherapy regimens}

From 1984-1992, 1282 patients received MMM (mitoxantrone $7 \mathrm{mg} \mathrm{m}^{-2}$ every 3 weeks, methotrexate $35 \mathrm{mg} \mathrm{m}^{-2}$ every 3 weeks, mitomycin C $7 \mathrm{mg} \mathrm{m}^{-2}$ every 6 weeks). From 1992 onwards mitomycin was excluded from the regimen since there was an increased incidence of haemolytic-uraemic syndrome (Montes et al, 1993), and the subsequent 492 patients were treated (in 1992-1995) with MM (methotrexate $35 \mathrm{mg} \mathrm{m}^{-2}$ every 3 weeks, and mitoxantrone $11 \mathrm{mg} \mathrm{m}^{-2}$ every 3 weeks). Patients also received local radiotherapy to the chest wall, and tamoxifen $20 \mathrm{mg}$ daily. Table 1 summarizes treatments and characteristics of patients in the MMM and MM groups.

\section{Diagnosis of MDS/AML}

MDS/AML was diagnosed using French-American-British (FAB) criteria (Bennett et al, 1982; 1985). Cytogenetic analysis was performed using conventional methods.

\section{Statistical methods}

Patients were considered to be at risk of developing MDS/AML from the initial date of treatment with MMM or MM until the last follow-up or death. The actuarial incidence was calculated by the life-table method of Kaplan and Meier (1958). A comparison of patients treated with MMM and MM was carried out using the Logrank test. Survival after diagnosis of MDS/AML was also ascertained by the life-table method.

The expected numbers of acute myeloid leukaemias and myelodysplastic syndromes in an age/sex matched population were calculated by applying the age- and sex-specific figures for leukaemias in England and Wales (supplied by the Office of Population Census and Surveys) assuming a Poisson distribution to the person-years at risk. The age-specific incidence figures for MDS were obtained from the data published by Williamson et al (1994). The relative risk of developing AML/MDS was calculated 
Table 1 Patients treated with MM/MMM

\begin{tabular}{lcc}
\hline & MMM & MM \\
\hline Number of patients & 1282 & 492 \\
Male/Female & $5 / 1277$ & $1 / 491$ \\
Age (median (range)) & $54(20-90)$ & $54(27-83)$ \\
Local RT $_{\text {No RT }}$ & 366 & 319 \\
RT (no information) & 214 & 84 \\
Number of courses & 702 & 89 \\
(median (range)) $_{\text {median }}$ & 6 & 6 \\
& $(1-15)$ & $(1-11)$ \\
\hline
\end{tabular}

a RT (local radiotherapy) data not available before April 1988

using the standardized incidence ratio, and confidence intervals are exact (Breslow and Day, 1987).

\section{RESULTS}

In the period 1984-1995 1774 patients received MMM chemotherapy ( $n=1282$, median age 54 years, range 20-90) or MM $(n=492$, median age 54 years, range $27-83)$ in adjuvant or neoadjuvant setting. Median follow-up was 5 years.

Five patients developed AML and four developed MDS after treatment with MTZ-based chemotherapy, giving an incidence of 15 per 100000 years follow-up. The median age was 60 years (range 45-68). Details of the cases of MDS and AML are shown in Table 2. On average, MDS/AML developed 2.5 years (range 1.3-7) following MTZ-based chemotherapy (Table 2). There was no difference in incidence between prior $\mathrm{MM}$ or $\mathrm{MMM}$ chemotherapy $(3 / 492$ versus $6 / 1282 ; P=0.9)$. The risk of developing MDS/AML at 5 and 10 years was calculated as $1.1 \%(95 \%$

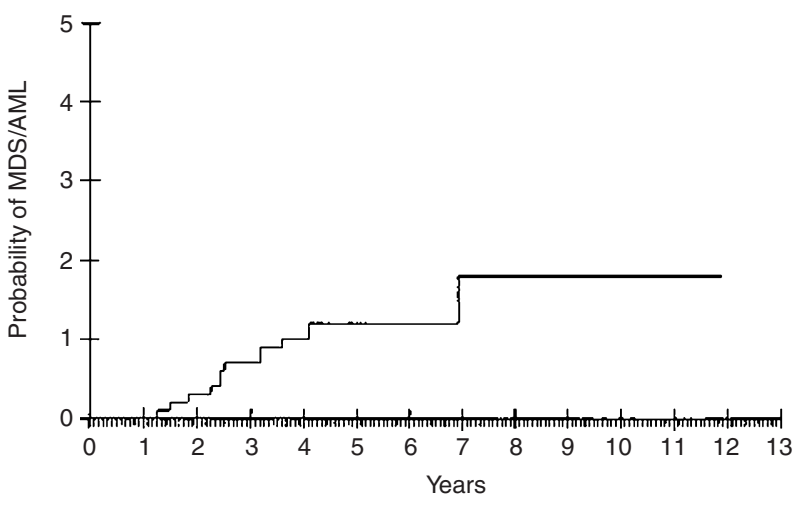

Figure 1 Incidence of MDS/AML after MZT-based chemotherapy.

CI: $0.6-2.2 \%$ ) and $1.6 \%$ (95\% CI: $0.7-3.6 \%$ ) respectively (Figure 1). The relative risk of developing MDS/AML was 10.1 times greater than in an age- and sex-matched normal population $(95 \%$ CI: 3.5-16.7). For MDS alone the risk was 8.6 times greater, and for leukaemia alone it was 14.1 times greater than in the normal population (Table 3).

Women with AML/MDS had received the following total drug doses: Mitoxantrone $80 \mathrm{mg}$ (range 60-162 mg), methotrexate $310 \mathrm{mg}$ (range $265-400 \mathrm{mg}$ ), in six cases with mitomycin $45 \mathrm{mg}$ (range 39-51 mg). In addition to MTZ-based chemotherapy, all patients had surgery and additional chest wall irradiation, while five patients in this group had adjuvant therapy with tamoxifen. An abnormal cytogenetic clone was present in eight cases, while one patient had no clonal abnormality. Five individuals had abnormalities involving chromosomes 5 and/or 7 , and three had

Table 2 Details of secondary MDS/AML patients

\begin{tabular}{|c|c|c|c|c|c|c|c|c|c|c|}
\hline \multirow[t]{2}{*}{ Case } & \multirow{2}{*}{$\begin{array}{l}\text { Age } \\
\text { (years) }\end{array}$} & \multirow{2}{*}{ Diagnosis } & \multirow{2}{*}{$\begin{array}{c}\text { Ca. Breast } \\
\mathrm{T} / \mathrm{T}^{\mathrm{a}}\end{array}$} & \multirow[t]{2}{*}{ Regimen } & \multirow{2}{*}{$\begin{array}{l}\text { Time to } \\
\text { AML/MDS } \\
\text { (years) }\end{array}$} & \multicolumn{3}{|c|}{ Total chemotherapy doses ${ }^{d}$} & \multirow[t]{2}{*}{ Cytogenetics } & \multirow{2}{*}{$\begin{array}{l}\text { Outcome } \\
\text { (months) }\end{array}$} \\
\hline & & & & & & Mitoxantrone & Methotrexate & Mitomycin & & \\
\hline$A$ & 64 & AML M7 & $\begin{array}{l}\mathrm{S}, \mathrm{CT}+\mathrm{RT} \\
\text { Tamox }\end{array}$ & MMM & 3.6 & $\begin{array}{l}68 \mathrm{mg} \\
(46.9)\end{array}$ & $\begin{array}{l}270 \mathrm{mg} \\
(186.2)\end{array}$ & $\begin{array}{l}39 \mathrm{mg} \\
(26.9)\end{array}$ & $45, X X,-7$ & $\begin{array}{l}\text { Dead } \\
2\end{array}$ \\
\hline $\mathrm{B}$ & 50 & AML M1 & $\mathrm{S}, \mathrm{CT}+\mathrm{RT}$ & MMM & 4.2 & $\begin{array}{l}60 \mathrm{mg} \\
(37.5)\end{array}$ & $\begin{array}{l}300 \mathrm{mg} \\
(187.5)\end{array}$ & $\begin{array}{l}45 \mathrm{mg} \\
(28.1)\end{array}$ & $47, \mathrm{XX},+$ mar & $\begin{array}{c}\text { Dead } \\
1\end{array}$ \\
\hline $\mathrm{C}$ & 71 & MDS/RA & $\begin{array}{l}\mathrm{CT}, \mathrm{S} \\
\mathrm{CT}+\mathrm{RT} \\
\text { Tamox }\end{array}$ & MMM & 3.2 & $\begin{array}{l}79 \mathrm{mg} \\
(45.1)\end{array}$ & $\begin{array}{l}310 \mathrm{mg} \\
(177.1)\end{array}$ & $\begin{array}{l}45 \mathrm{mg} \\
(25.7)\end{array}$ & $46, X X$ & $\begin{array}{l}\text { Dead } \\
10\end{array}$ \\
\hline $\mathrm{D}$ & 46 & AML M2 & $\begin{array}{l}\mathrm{CT}, \mathrm{S}, \\
\mathrm{CT}+\mathrm{RT}\end{array}$ & MM & 1.3 & $\begin{array}{c}162 \mathrm{mg} \\
(93.1)\end{array}$ & $\begin{array}{l}400 \mathrm{mg} \\
(229.9)\end{array}$ & nil & 46, XX, t(8;21)(q22;q22) & $\begin{array}{c}\text { In CR1 } \\
60\end{array}$ \\
\hline$E$ & 75 & $\begin{array}{c}\text { MDS } \\
\text { Hypoplas }\end{array}$ & $\begin{array}{l}\mathrm{HAD}^{\mathrm{c}}, \mathrm{S} \\
\mathrm{HAD}+\mathrm{RT}\end{array}$ & $\begin{array}{l}\mathrm{MM} \\
\mathrm{FEC}^{\mathrm{b}}\end{array}$ & 2.5 & $\begin{array}{l}96 \mathrm{mg} \\
(59.6)\end{array}$ & $\begin{array}{l}320 \mathrm{mg} \\
(198.8)\end{array}$ & nil & $\begin{array}{l}\text { 46, XX, del(1)(p32p34), } \\
\operatorname{del}(5)(q 13 q 33), \\
\operatorname{der}(7) t(7 ; 12)(q 3 ; q 13), \\
\operatorname{der}(12) t(7 ; 12)(q 22 ; q 13)\end{array}$ & $\begin{array}{c}\text { Dead } \\
17\end{array}$ \\
\hline $\mathrm{F}$ & 58 & AML M3 & $\begin{array}{l}\text { CT, S, CT, } \\
\text { RT, Tamox }\end{array}$ & MM & 1.8 & $\begin{array}{c}126 \mathrm{mg} \\
(70)\end{array}$ & $\begin{array}{l}300 \mathrm{mg} \\
(166.7)\end{array}$ & nil & $\begin{array}{l}46, X X, t(1 ; 2)(p 22 ; q 21) \\
t(15 ; 17)(q 22 ; q 21)\end{array}$ & $\begin{array}{c}\text { In CR1 } \\
18\end{array}$ \\
\hline G & 66 & $\begin{array}{l}\text { MDS } \\
\text { RARS }\end{array}$ & $\begin{array}{l}\text { CT, S, CT, } \\
\text { RT, Tamox }\end{array}$ & MMM & 2.4 & $\begin{array}{l}77 \mathrm{mg} \\
(38.5)\end{array}$ & $\begin{array}{l}265 \mathrm{mg} \\
(132.5)\end{array}$ & $\begin{array}{c}50 \mathrm{mg} \\
(25)\end{array}$ & $\begin{array}{l}45, X X, \operatorname{del}(3)(p 12),-7, \\
-9 \operatorname{add}(17)(p 1),-8,+ \text { mars } / \\
45, X X, \text { idem, del }(5)(q 3)\end{array}$ & $\begin{array}{l}\text { Dead } \\
8\end{array}$ \\
\hline $\mathrm{H}$ & 62 & MDS & $\begin{array}{l}\text { S, RT, } \\
\text { Tamox }\end{array}$ & MMM & 7 & $\begin{array}{l}93 \mathrm{mg} \\
(51.7)\end{array}$ & $\begin{array}{l}320 \mathrm{mg} \\
(177.8)\end{array}$ & $\begin{array}{l}51 \mathrm{mg} \\
(28.3)\end{array}$ & $46, \mathrm{XX},-7,+$ mar & $\begin{array}{c}\text { Alive } \\
12\end{array}$ \\
\hline 1 & 77 & AML M2 & $\begin{array}{l}\text { S, RT, } \\
\text { Tamox, } \\
\text { VAC/VEC }\end{array}$ & MMM & 2.4 & $\begin{array}{l}80 \mathrm{mg} \\
(53.3)\end{array}$ & $\begin{array}{c}400 \mathrm{mng} \\
(260.6)\end{array}$ & $\begin{array}{l}40 \mathrm{mg} \\
(26.6)\end{array}$ & $\begin{array}{l}\text { 45, XX, add(5)(q15), der(11) } \\
\operatorname{add}(11)(p 15) \operatorname{add}(11)(q 23), \\
-18, \operatorname{del}(20)(q 13)\end{array}$ & $\begin{array}{l}\text { Dead } \\
\text { 27days }\end{array}$ \\
\hline
\end{tabular}

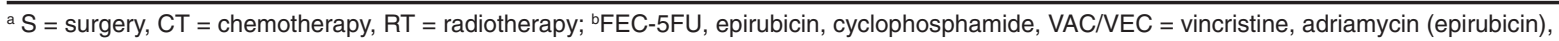
cyclophosphamide, Tamox = tamoxifen; 'HAD-hydroxyandrostenedione; ${ }^{\mathrm{d} T o t a l}$ dose in $\mathrm{mg}, \mathrm{mg} \mathrm{m}^{-2}$ in parentheses 
Table 3 Relative risk (RR) of developing MDS/AML compared to an ageand sex-matched population

\begin{tabular}{lcccc}
\hline & No. of cases & $\mathbf{R R}$ & $\mathbf{9 5 \%} \mathbf{C l}$ & Significance \\
\hline MDS/AML & 9 & 10.1 & $3.5-16.7$ & $P<0.01$ \\
MDS & 4 & 8.6 & $0.2-17.0$ & $P<0.1$ \\
AML & 5 & 14.1 & $2.8-25.4$ & $P<0.05$ \\
\hline
\end{tabular}

complex abnormalities. Other chromosome abnormalities included $\mathrm{t}(8 ; 21), \mathrm{t}(15 ; 17)$ with $\mathrm{t}(1 ; 2)$, and one patient had an unidentified additional abnormality (Table 2 ).

Patient outcomes are shown in Table 2. All five patients with AML were treated with chemotherapy. Two are alive, and three died of chemotherapy-related problems. Four patients with MDS were over 60 years-of-age and were managed with supportive care alone; three have died. In one patient the MDS evolved into AML.

\section{DIscussion}

There has been significant improvement in survival and cure expectancy for patients with breast cancer due to combined modality treatment using surgery, chemotherapy and radiation. Selection of the optimum form of combination chemotherapy for breast cancer should take into account associated long-term risks. The CMF regimen is a standard regimen for adjuvant treatment and its long-term benefit has been established. However, there is a potential risk of secondary leukaemia associated with most of these drugs (Henderson et al, 1990).

Aul et al (1992) have shown that the risk of developing MDS/AML increases with age; the average annual incidence in all age-groups in the period 1986-1990 was 4.11 per 100000 per year, with a considerable rise of incidence in the older population. The average incidence in the population $>70$ years-of-age was 22.81 per 100000 per year (33.88 for men and 18.02 for women), while the incidence of AML is 6.7 per 100000 per year. Another study has confirmed an increased incidence of MDS in older patients (Williamson et al, 1994).

We assessed the incidence of MDS and AML occurring in a cohort of patients with breast cancer treated with mitoxantronecontaining regimens. The current report is one of the largest analyzing risk of secondary acute myeloid leukaemia after mitoxantrone in breast cancer patients. With a median follow-up of 5 years, there were nine cases of AML/MDS among 1774 patients giving a crude incidence of 15 per 100000 years of follow-up.

Bonadonna et al (1993) noticed a cumulative risk of $0.23 \%+/-$ $0.15 \%$ at 15 years, and a relative risk $2.3 \times$ greater compared to the normal population after a median follow-up of 12 years in patients receiving CMF. However, the Eastern Cooperative Oncology Group (ECOG) found a crude incidence rate of 26 per 100000 years of follow-up for a secondary haematological malignancy after treatment with standard adjuvant chemotherapy, which with standard dose cyclophosphamide was not much higher than that seen in the general population (Tallman et al, 1995).

To improve tumour response rates and prolong survival, anthracycline-based regimens have been introduced, with results at least as good as those seen with CMF. However, the risk of secondary AML with doxorubicin-containing regimens has been found to be $1.5 \%(0.7-2.9 \%)$ at 10 years (Diamandidou et al, 1996) and the risk was significantly higher after chemoradiotherapy than after chemotherapy alone (10 year actuarial risk of $2.5 \%$ vs $0.5 \%$ ). Mitoxantrone may be less toxic and has also been used more recently in combination chemotherapy for breast cancer (Powles et al, 1991).

To our knowledge there is no association between mitomycin and methotrexate and hematological malignancies (Rustin et al, 1996), and there are few reports concerning a possible leukaemogenic effect of mitoxantrone (Philpott et al, 1993; Mitchell et al, 1996). Therapy-related or secondary leukaemias often show cytogenetic abnormalities, and there are characteristic differences which may be specific for particular chemotherapy agents; alkylating agents are associated with abnormalities of chromosomes 5 and 7 while topoisomerase-II inhibitors are associated with chromosome 11 abnormalities. (Ellis et al 1993; Smith et al, 1996).

In our study, $67 \%$ of patients had predominantly unbalanced chromosome aberrations that are associated with prior radiotherapy and/or alkylating agent treatment, but not with mitoxantrone therapy. However, all the patients with MDS/AML had also received radiotherapy and hence it is possible that in our patients the risk of MDS/AML was more likely to be associated with the combination of chemotherapy and radiotherapy (Johansson et al, 1996).

Two patients in this series who had balanced translocations had a family history of cancer. One had a sister with brain cancer, while the other had a mother with lung cancer and a sister with breast cancer. Because of their family backgrounds, these patients may be in a high-risk category and more prone to developing a secondary malignancy; MDS/AML in this situation is more likely to represent a second primary rather than a secondary haematological malignancy (Thirman and Larson, 1996). An increased family incidence of haematological malignancies in these cases may also indicate a role for oncogenes and tumour suppressor genes in the development of MDS/AML (Skuse and Ludlow, 1995).

\section{CONCLUSION}

Our study has shown an increased incidence of MDS and AML after MTZ-based chemotherapy, compared to that seen in the general population. However, it is difficult to estimate how much of this is due to the MTZ-based chemotherapy rather than to the population being at higher risk because of family history, age or additional treatment with chemo/radiotherapy.

\section{ACKNOWLEDGEMENTS}

We are grateful to Ms Carol Brooker of Queen's Hospital, Croydon, for cytogenetic data of case $\mathrm{H}$.

\section{REFERENCES}

Aul C, Gattermann N and Schneider W (1992) Age-related incidence and other epidemiological aspects of myelodysplastic syndromes. Br J Haematol 82: 358-367

Bennett JM, Catovsky D, Daniel MT, Flandrin G, Gahon DA, Gralnick HR and Sultan C (1982) FAB Cooperative Group. Proposals for the classification of myelodysplastic syndromes. Br J Haematol 51: 189-199

Bennett JM, Catovsky D, Daniel MT, Flandrin G, Galton D, Gralnick HR and Sultan C (1985) Proposed revised criteria for the classification of acute myeloid leukemia. Ann Intern Med 103: 620-625 
Bonadonna G, Valagussa P, Moliterni A, Zambetti M and Terenziani M (1993) Risk of acute leukemia and other malignances following CMF-based adjuvant chemotherapy for breast cancer. Proceedings of the American Society of Clinical Oncologists 12: 61 (abstr 45)

Bonadonna G, Valagussa P, Moliterni A, Zambetti M and Brambilla C (1995) Adjuvant cyclophosphamide, methotrexate, and fluorouracil in node-positive breast cancer. The results of 20 years of follow-up. N Engl J Med 332: 901-906

Breslow NE and Day NE (1987) The design and analysis of cohort studies. In Statistical methods in Cancer Research, Vol 2. pp 1-406. IARC Scientific Publications: Lyon

Brincker H, Rose C, Maase H and Dombernowsky P (1983) A randomized study of CAF-TAM (Tamoxifen) versus CMF + TAM in metastatic breast cancer. Proceedings of the American Society of Clinical Oncologists 3: 113

Diamandidou E, Buzdar AU, Smith TL, Frye D, Witjaksono M and Hortobagyi GN (1996) Treatment-related leukemia in breast cancer patients treated with fluorouracil-doxorubicin-cyclophosphamide combination adjuvant chemotherapy: The University of Texas MD Anderson Cancer Center Experience. J Clin Oncol 14: 2722-2730

Ellis M, Ravid M and Lishner M (1993) A comparative analysis of alkylating agent and epipodophyllotoxin-related leukemias. Leuk Lymphoma 11: 9-13

Fisher B, Dignam J, Wolmark N, DeCillis A, Emir B, Wickerham DL, Bryant J, Dimitrov NV, Abramson N, Atkins JN, Shibata H, Deschenes L and Margolese RG (1997) Tamoxifen and chemotherapy for lymph nodenegative, estrogen receptor-positive breast cancer. J Natl Cancer Inst $\mathbf{8 9}$ : $1673-1682$

Henderson IC, Garber JE, Breitmeyer JB and Hayesris JR (1990) Comprehensive management of disseminated breast cancer. Cancer 66: 1439-1448

Johansson B, Mertens F and Mitelman F (1996) Secondary neoplasia-associated chromosomal abnormalities-Balanced rearrangements vs genomic imbalances? Genes Chromosomes Cancer 16: 155-163

Kaplan EL and Meier P (1958) Nonparametric estimation from incomplete observations. American Statistical Association Journal 53: 457-481

Mitchell PL, Treleaven JG, Swansbury GJ, Powles RL, Ashley S and Powles T (1996) Secondary acute myeloid leukaemia (AML) and myelodysplasia (MDS) following mitoxantrone given as adjuvant therapy for breast cancer. Proceedings of the American Society of Clinical Oncologists 12: 127

Montes A, Powles TJ, O'Brien ME, Ashley SE, Luckit J and Treleaven J (1993) A toxic interaction betwen mitomycin $\mathrm{C}$ and tamoxifen causing the haemolytic uraemic syndrome. Eur J Cancer 29A: 1854-1857

Pedersen-Bjergaard J and Rowley J (1994) The balanced and unbalanced chromosome aberrations of acute myeloid leukemia may develop in different ways and may contribute differently to malignant transformation. Blood 83: 2780-2786

Philpott NJ, Bevan DH and Gordon-Smith EC (1993) Secondary leukaemia after MMM combined modality therapy for breast carcinoma. Lancet 341: 1289

Powles TJ, Jones AL and Judson IR, et al. (1991) A randomised trial comparing combination chemotherapy using mitomycin $\mathrm{C}$, mitoxantrone and methotrexate (3M) with vincristine, anthracycline and cyclophosphamide (VAC) in advanced breast cancer. Br J Cancer 64: 406-410

Powles TJ, Hickish TF, Makris A, Ashley SE, O’Brien M, Tidy VA, Casey S, Nash A, Sacks N, Cosgrove D, MacVicar D, Fernando I and Ford HT (1995) Randomized trial of chemoendocrine therapy started before and after surgery for treatment of primary breast cancer. J Clin Oncol 13: 547-552

Rustin GJS, Newlands ES, Lutz JM, Holden L, Bagshawe KD, Hiscox JG, Foscett M, Fuller S and Short D (1996) Combination but not single-agent methotrexate chemotherapy for gestational trophoblastic tumors increases the incidence of second tumors. J Clin Oncol 14: 2769-2773

Skuse GR and Ludlow JW (1995) Tumour suppressor genes in disease and therapy. Lancet 345: 902-906

Smith MA, McCaffrey RP and Karp JE (1996) The secondary leukemias: Challenges and research directions. J Natl Cancer Inst 88: 407-418

Tallman MS, Gray R, Bennett JM, Variakojis D, Robert N, Wood WC, Rowe JM and Wiernik PH (1995) Leukemogenic potential of adjuvant chemotherapy for early stage breast cancer: The Eastern Cooperative oncology group experience. J Clin Oncol 13: 1557-1563

Thirman MJ and Larson RA (1996) Therapy related myeloid leukemia. Hematol Oncol Clin North Am 10: 293-320

Williamson PJ, Kruger AR, Reynolds PJ, Hamblin TJ and Oscier DG (1994) Establishing the incidence of myelodysplastic syndrome. Br J Haematol 87 : $743-745$ 